Zlatko Bukač

University of Zadar

\title{
The Marvel of the American Dream in The $X-M e n$ Graphic Novels and Comic Books
}

The point of debate that is the focus of this paper is the position of graphic novels and comic books in relation to the (de)construction of the notion of the American Dream. This notion is, as one would suggest, heavily influenced by perpetuated notions of American national identity, which is discursively constituted with tolerance towards people from other parts of the world who can fulfill their dreams and get a better life in America, while the system enables that kind of chance and provides protection from any kind of danger and injustice that exists in other countries. To make the American Dream more firmly posted within the construction of American national identity, the relationship has to be reciprocal. When these values of America as a perfect nation that protects its people are established through discourse, by following Benedict Anderson's concept of nation as the imagined space of collective belonging, the citizens who enjoy this kind of perceived security and opportunity attach themselves to that imagined space. This paper proposes that the concept of citizenship is a part of enabling someone to feel they are part of the American nation, which is formed with values that are established and perpetuated within popular media (including graphic novels). By relying on Lauren Berlant's work on the construction of citizenship through specific narratives in popular culture, this paper focuses on the representation(s) of race, racism, and tolerance in superhero narratives that are seen as an integral part of American popular culture in establishing discourses about the American Dream and American national identity. The paper aims at addressing the specific case of the X-Men series, specifically the Giant Size X-Men issues, as an example that actively problematizes themes such as intolerance and diversity related to race while at the same time perpetuating different other discourses that stereotype certain nations and ethnicities. The paper attempts to determine specific practices for American citizenship in relation to the American Dream and the representation of the American Dream that is dependent on representation practices of race, ethnicity, and gender in the aforementioned X-Men canon. 
Key words: American popular culture, comic books, cultural citizenship, difference, discourse analysis, visual analysis, race, gender, ethnicity

Upon their inception during the late 1930s, superhero comic books were immediately labeled as something that contained the attributes of a low-culture product, and the label stuck until many cultural theorists pointed them out as something that should be understood as popular culture. Through their extravagant and science-fiction themes and impossible premises, including people jumping off buildings, wearing masks, and exhibiting extraordinary abilities, they were grounded only in a manner of addressing certain political and social issues of their time. Beginning with World War II, continuing through the era of moral panic about youth culture, and eventually referencing the feminist and Civil Rights movements, superhero comic books and graphic novels, as a special genre of comic book, solved American political problems with ease. Today, superheroes are retrospectively labeled as "the defining fantasy of the comic book form" (Hassler-Forest 6). With most of their narratives, motifs, and tropes derived from penny dreadful novels and other forms of American popular literature such as pulp fiction, comic-books managed to fuse image and text into a substantial form that eventually dispersed into various sub-genres, creating their own narrative strategies and establishing new tropes that influenced popular culture on a much wider scale. Consequently, they managed to address, sometimes reinforce, and criticize as well, political and cultural trends that were happening at home - in the United States. In that manner, comic-books can be used "as significant cultural artifacts from the past" (Neuhaus in Pustz 11) which, as many other artifacts of the same manner, give us certain information about the time, as well as the social and cultural context within which they have been developed. Within cultural theory, the mode of surpassing "structural formalism" (Smith and Riley 183) posits these comic-books as more ambivalent products that divulge different themes and ideologies which are constantly being reshuffled between the text and the reader. This article attempts to focus on one of those positions where certain denotations and connotations can be 
seen as valuable factions in composing certain meta-texts within American society that started in the 1950 s and are still perpetuated through superhero narratives today as well.

The rise of the popularity of superhero comic books and graphic novels, together with their increasingly successful film and television adaptations, undeniably raises questions of its value and contribution to contemporary social and cultural discourses. These discursive tendencies are important within a strictly American context, as well as on a larger global scale. A particular point of debate when discussing the position of comic books within the American context is their relation to the (de)construction of the American Dream, as well as to their role in the construction of the dominant representation of a true American (in terms of race, class, and gender). The notion of the American Dream is, as one would suggest, heavily influenced by perpetuating values of national identity as well as by the notion of citizenship. In her work on the citizenship model, Lauren Berlant extrapolates its cultural significance as something that is relational, among strangers who occupy the same space of a certain nation state ("Citizenship" 37). These relations are noted in Benedict Anderson's work on nation as an imagined community, which he relates to the process of identification, in which there has to be a conceived "deep, horizontal comradeship" (7). Noting these insights, this paper postulates that the concept of citizenship is an important part of enabling someone to be a part of the American nation (their sense of belonging) and that the specific values of this nation can be established and perpetuated within the popular media (including comic books). This enabling is closely related to the ability of the citizen to understand, respect, and live the American Dream to its fullest. Taking this into consideration, the paper focuses primarily on the effect of superhero narratives in the context of forming a sense of belonging to or detachment from the nation in analyzed superhero discourse. The question arises about what happens to people in the United States who do not fit in, who immigrated there, or who are visually not immersed or recognized (because of race, sexual orientation, or gender) as truly American. The issue of not having the same values and postulated feelings of comradeship, due to a 
person's arrival in the nation state as a stranger or being labeled as such because of racial and other social characteristics is something that posits a question about the role of cultural citizenship. Berlant notes "cultural citizenship" as a term that describes the history of subordinated groups and the ways in which they fit in the grand narrative of national belonging ("Citizenship" 41). This kind of belonging is not the part of official and legal narratives but is related to different representation practices within (popular) culture. ${ }^{1}$

Following Berlant's work on the consistency of various popular culture narratives in articulating different aspects of American national identity, this paper tries to unravel these discursive practices in one particular product of popular culture which has been ignored - superhero comic books. It should be noted that this paper cannot analyze all distinctive and diverse issues and themes within this "uniquely American phenomenon" (Regalado 84) nor does this paper establish a universal reading of selected texts. Rather, it tries to provide insight into the inception and narrative development of superhero comic books on the basis of one specific case that acknowledges racial and ethnic differences in the United States, and it tries to approach this case in relation to the construction of citizenship, which is connected to the discourse on the American Dream. The wish to fulfil the American Dream that becomes evident through narratives on establishing this fulfillment is an additionally important aspect for this analysis, as it provides some answers to questions about how popular culture's construction of citizenship relates to specific issues connected with the representation of race.

This study approaches American superhero comic books in two ways: firstly as a certain critique of the situation in the United States, and secondly as an indicator of the representation of citizenship models in America but also in the rest of the world, which is heavily influenced by American popular culture. The X-Men comic books have had a specific narrative since their

1 For more on this topic, read Lauren Berlant's work on nation, fantasy, and citizenship that is problematized and analyzed in works such as The Anatomy of National Fantasy and Queen of America Goes to Washington City: Essays on Sex and Citizenship 
inception in 1963, with allegories that relate to the African-American Civil Rights Movement and ongoing xenophobia combined with human rights debates concerning people who do not fit in the grand narrative of the American citizen. The aim of this paper is to analyze discourse ${ }^{2}$ (visual as well as textual) to determine specific practices concerning American citizenship in relation to the American Dream and representations of the American Dream that are dependent on the racial, ethnic, and gender representation practices used in the aforementioned $X$-Men canon. Text does not have a specific strength or function without meaning, and the essential part of producing and exchanging meaning, according to Stuart Hall, is representation (17). If we take into consideration Hall's statement that "Representation is the production of the meaning of the concepts in our minds through language" (Hall 17 ), then it should be possible to determine what kind of discourse(s) determine attributes that construct or reinforce the dominant hegemonic sphere of a certain nation or culture. Consequently, it is possible to analyze certain ideological images of a perfect citizen. An important aspect of this kind of premise is that the perfect citizen is embedded in the imagined space of national belonging, enhanced by the fulfillment of the American Dream. In that notion, this paper aims to point out how and in what way this imagined space of national belonging is articulated in specific superhero comic books (and thus in a specific public sphere).

Comic books and graphic novels enter the public sphere due to their popularity and distribution; there, they create specific modes of belonging (such as whiteness and heteronormativity ${ }^{3}$ ) to the dominant hegemonic

2 Methodologically, it is also important for this analysis to note that discourse is considered within Sara Mills' view as "a domain for written and oral communication" (7) and, by locating her analysis in Foucault's work on discourse theory, acknowledging in such a way that every text has meaning and consequences for the so-called real world. All discourses, according to Foucault, make a group of written or spoken acts which are regulated in some way and constructed by a particular force (Mills 7).

3 This, as well as many other modes, is something that Lauren Berlant writes extensively in her works, one of which is Cruel Optimism. 
sphere of a certain nation or culture, isolating those individuals who do not possess these specific modes due to their skin color, place of origin, or sexual orientation. But how are these ideological images transferred in The X-Men, and how strong is their role in rendering the nation supreme and powerful?

\section{The Superhero Phenomenon}

Superheroes, a product upon which the two biggest comic book publishing houses, Marvel Comics and Detective Comics, depend, have been a part of popular culture since the first appearance of Superman in 1938. Marvel and DC have always had a strong presentation of their superheroes in the context of relating them to specific contemporary political and social situations. Anderson's viewpoint on the nation as a community that is socially constructed and imagined by the people, is something that coincides with the ways in which we think about the popularity of the first superhero comic books, specifically and especially Captain America.

Captain America, one of the most famous superheroes, appeared during World War II by punching Hitler in the face on the cover of the first issue. He enforced the perpetuation of American identity and maintained a sense of security and collectiveness during the war. He did so within various situations in which he confronted the Nazis, Japanese soldiers, and foreigners in general who were portrayed (visually, as well as textually) as a threat to the American way.

Not so long after that, superheroes became the dominant medium of youth culture, appearing in radio shows, on television, in parades, and in commercial stores as well as in comic books. The first few years (during World War II) were pivotal, when critiques of politicians, corrupted elites, and police officers were developed, as they were seen as among the most important aspects (and reasons) for the economic crisis and decreased quality of life for the working class. Superheroes were positioned as a means of confronting the perceived enemies of American society while protecting the "little people". It did not take long for superhero comic books and their authors to start commenting on other social issues in American society and 
reflecting on them in different ways - sometimes reinforcing and sometimes fighting certain stereotypes and preconceived misconceptions. They promptly started to have a big role within the popular culture apparatus, similar to how newspapers formed a specific imagined world where their readers developed a sense of collective, a sense of unity that for Anderson constitutes the nation as an imagined community (63). Even though maintaining certain predominating hegemonic values of an archetype superhero as someone who is good-looking, white, and male, Marvel and DC offered specific female and black superhero stories in different periods of social and political upheaval. In an attempt to comment on them by providing new types of superheroes, these comic books would perpetuate more of the same values appropriated from previous discourses on the American way of life and citizenship, as the example with The X-Men will point out. Relying on Foucault's notion of discourse that functions as a certain "regime of truth" (316), we can focus on the type of superheroes and their values that have been perpetuated in discourse until this day. With various ethnicities, races, empowered female characters, the ideal types and most recognizable superheroes are still nonetheless most accepted and popular in the form of white men. This is a notion that becomes more evident in the analysis of Marvel's The X-Men.

\section{White Male Dominance and The X-Men}

There can be different strategies in perpetuating the values of an imagined political community (Anderson 6) and one of specific interest to this article is the strategy of creating additional differences within an already different people in that community (different in the context of representation). In this case, they are mutants, specific humans (not aliens) with specific abilities (not superpowers) that make them heroes, villains, or innocent bystanders (minorities who suffer and wait for some change). As they are exposed to the rest of (American) society, mutants suffer a great deal of prejudice and discrimination from people who are scared of or angry at them. Although, as products of evolution, they are superior, they are seen as mistakes and dangerous because of their abilities. Very early in The X-Men issues, a differ- 
ence was established between mutants and humans, and the stories often dwelled on the question of equality, making the issues of racism and bigotry main themes for the X-Men narratives. The central conflict was the conflict between ideologies, personified in the good Mutants (X-Men) and the bad ones (Brotherhood of Mutants). The X-Men, led by Professor Charles Xavier (Professor X), advocates for peace between humans and mutants, while the Brotherhood and their leader, Max Eisenhardt (Magneto), have opposing views regarding that relationship, refusing possibilities of peaceful coexistence between humans and mutants. These two characters symbolize different ideologies similar to the Civil Rights Movement and the major figures behind it - specifically, Martin Luther King and Malcolm X. Although the writers never admitted or acknowledged this, many previous analyses conducted by fans and media have pointed out this connection. X-Men mirrored that situation and dealt with racism and homophobia in America through the allegory of superhuman mutants.

The representation of non-white characters, especially black characters, was heavily stereotyped during the 1950s and 1960s. They were short-tempered, spoke with bad grammar, and had distinguished physical characteristics. In the case of the X-Men, this was not the case because black characters were basically non-existent. Even though the theme was about race and prejudice, all the primary members of the X-Men were white males, with the exception of one white female. The narration of difference in The X-Men was dealt with through the presence of whiteness even though the theme in a certain way demanded that the comic book be more racially diverse. If we take Gillian Rose's insight on discourse, where she emphasized the importance given to things that are said or written as well as to things which are not being said (Rose 157), then we can state that in ignoring the race aspect from one deeply imbedded racial premise, the discourse established here started to form an ideal citizen within a white milieu. The only female X-Man at that time was Jean Grey, a mutant with telekinetic abilities who was objectified and teased by the other, male members of the team. Even though the main theme was established as an allegory and representation of real racial and 
sexual conflicts in society in the '60s, it has long been a fight in which handsome, confident, and able white men (and one woman) are led by an elder white man in battle and constant conflict with the Brotherhood of Mutants, who were mostly white men as well (although not so physically perfect as the $\mathrm{X}$-Men members). In that way, the approach of comic book writers at that time was still aimed at whiteness within the population, addressing serious issues but in the end forming a national rhetoric for being a model American citizen knowing that acceptance will come first and foremost if you are visually and culturally part of the dominant, and to put it in Berlant's terms, hegemonic white male patriarchy that can be one of the aspects of national fantasy (Queen of America 5). The importance of noting the beginning of the $X$-Men canon is in labeling the context more precisely and, in doing so, concentrating on the issue which finally addressed the fact that the white $X-M e n$ are not alone in the world and that the United States of America is not the only place where these kinds of (fictional) problems could arise. In the tendency of "mapping the context within which discourse is used as a term needed to narrow the range of possible meanings" (Mills 3), the focus of this analysis is on the later expansion of the X-Men team and its use of the ideology of the American Dream to disrupt and reinforce the already established notion of the ideal American citizen with additional attributes. The paper will now focus on the answers for what kind of additional attributes there are in the X-Men comic-book and how it "articulates" (Laclau and Mouffe 105) a representation of citizenship models in America. ${ }^{4}$

\section{More Diverse X-Men - How the American Dream Worked}

By the end of the 1970s, Marvel started to expand the core group of $\mathrm{X}-\mathrm{Men}$ by adding mutants of different races and ethnicities, which should have made their representation of racist struggles and critique of intolerant

4 Articulation is "any practice establishing a relationship among elements such that their identity is modified as a result of the articulatory practice," while a discourse is "the structured totality resulting from this articulatory practice" (Laclau \& Mouffe, 1985: 105 in Stavrakakis, Norval and Howarth 7). 
societies more concrete. Nonetheless, as was evident in other superhero series by Marvel and DC, the attempts to present a difference often backfired because of additional stereotyping of certain aspects of society and its members. This was done in 1975 with the Giant Size X-Men series, in which Professor Xavier decided to recruit additional members to fight a new threat but also to attend his School for Gifted Youngsters, an institution that was working within the X-Men mansion. The mansion functioned as a sanctuary, but also as an educational institution, with X-Men members teaching young mutant kids how to handle their powers and deal with the social problems that came with them. Cantor sees the educational aspect as the part of the vision of the American Dream, noting that "this vision of the American Dream was bound up with trust in American institutions. The goal of long-term security rested on faith in financial institutions (... ) Americans also looked up to their educational institutions, from primary schools to universities” (Cantor). Therefore, the purpose of the X-Men was not only to discern the nation, the world, or the people from external threats and other mutants, but it also had an educational function that offered a certain control and surveillance of its members, thus embracing another important aspect of the American Dream. The Giant Size X-Men series served as a link between the original X-Men and a new team of mutants coming from different parts of the world and, in doing so, added much needed diversity to an otherwise not-so-diverse group of different people. The new team consisted of seven people, gathering some members who were known to readers from earlier issues together with completely new ones. Sunfire, who was from Japan, had first been portrayed as a villain who hated America but later changed his ways to protect mutants with his ability of solar radiation (clearly referencing the atomic bomb that was dropped on Hiroshima). Wolverine, a masculine Canadian anti-hero with a short temper who had appeared in earlier issues and gained popularity, was also included in this new generation. The last mutant who was known from previous issues was Banshee, from Ireland, who possessed a sonic scream. His name and attributes were appropriated from Irish mythology and the creature of the same name. These three heroes had supporting roles due to 
introduction of new ones. The remaining four were given considerably more pages in these issues, making their characterization and representation the main source of narratives concerning the American Dream.

Marvel's tendency to make X-Men more international and diverse continued with first of the four new members - Nightcrawler, a mutant from Germany with dark blue skin, three fingers on each hand, and a tail as a side effect of his mutant powers. The pages of the comic book denote images of villagers chasing Nightcrawler with pitch-forks and fire in an effort to punish and kill him. The setting was portrayed as a village full of "monsters with mindless prejudices" that had "hardly changed over the years" (Marvel Comics 3). By placing these mindless, prejudiced people in a rustic foreign place, the authors conveyed two messages - one was that this kind of behavior belongs to the past and should no longer exist today, and the second was that, if it does exist and if it is a problem, then it is only a problem of other countries. Consequent to the latter, racism must be connected with explicit violence as presented here. While elaborating on the ideal of American citizenship, Berlant notes that "a modern American citizenship is derived from franchising African Americans” (Queen of America 13). In many cases, this sort of tendency can be applied to all people who are labelled as different and in similar discourse code as is used to so label African Americans. In the case of X-Men, this role can be filled by Europeans, Asians, and Native Americans, as well. Following the culturally based concept of the nation, according to which the nation is an area of integrative social inclusion, the expansion of this space puts citizens in the isolated specter of the publicity which claims to represent them. Europeans, and, for that matter, every American who is different from the majority (immigrants, minorities, etc.), are in this way included in the culturally formed nation and citizenship. In this inclusion, residues of such representations that signify them as different still persist and are therefore still trapped in that different publicity, different perception by the majority. Berlant notes that these kinds of transformations enforce the idea of the American Dream, a sort of utopia which the Americans already dwell in or aspire to (Queen of America 3-4). By exponentiating this notion, in the case 
of Nightcrawler we see its alternative if he refuses to go to the United States when he has been given a chance - he will be stalked or burned alive in the ancient, primeval backdrop of a European state. These notions become clearer in the case of the second new member, Storm, a black, female character from Africa who can control the weather and is "only happy here among the elements" (Marvel Comics 9). Her home is portrayed as inhabited by tribal people who are scantily clothed and bear tribal insignias on their bodies, depicting the established image of Africa as a savage, more primitive continent, where the inhabitants have established a more prolific connection to nature. This wild connection to nature is portrayed in Storm's abilities and in her short-tempered and unpredictable manner. She is additionally portrayed as a barefoot goddess with long silver hair, eyes that are "crystal blue and older than time" (Marvel Comics 8), white pupils, and tribal accessories. Her being depicted as a goddess by her own people connotes the ambivalence of a non-American, mostly Oriental religious system that is usually portrayed through American popular culture before and after these comic book issues. All these differences are well-established differences between the West and the East, as they have often been perpetuated in literature other than graphic novels and comic books.

The third new member is Colossus, a white man, but from Siberia, a strong and naïve mutant who works in his village and leads a simple life. When Professor Xavier approaches him and offers him the opportunity to go to America, he is perplexed by that image, and the question that he poses - To whom does his power belong? - is something that creates a dichotomy between Russia and the United States. As a Russian, he is convinced that his abilities and his work belong to the state, but the American leader of the $\mathrm{X}$-Men explaines that in America his powers are free, free in a manner that "belongs to the world" (Marvel Comics 12). Again, we can observe discourse mechanisms of establishing difference, in this case political and legal in human rights (or mutant rights), positioning the American system as better and fairer.

Thunderbird is the last one that Professor $\mathrm{X}$ tries to recruit, and for 
Thunderbird he does not have to go outside the United States. He is an Apache, and he possesses superhuman athletic ability. Before becoming a member of X-Men, he is enlisted in the United States Marine Corps during the Vietnam War; he is therefore already a part of America. The character of Thunderbird is portrayed as short-tempered, wild, eager to prove his strength, and, once he has accepted membership, his costume visually depicts Native American details such as a feather and boots. In this way professor $\mathrm{X}$ convinces him to join the X-Men by making Thunderbird react to his accusations that "the Apache are all frightened, selfish children" (Marvel Comics 14). The mystification of Native Americans by noting pride, dreams, and warrior abilities is something that is and has always been quite frequent in Hollywood cinema and other popular culture products. In this way, even though sharing the same space and laws as other American citizens who are in the position of power, Native American characters are differentiated from other members by cultural aspects such as clothes.

It is important to note that, while they all form a certain kind of stereotyped characteristics, they also, to put it in Stuart Hall's terms, connote that this kind of difference can only be imported to United States from other countries, thus distancing Asian-Americans and African-Americans from the feeling of being able to establish the dominant citizenship construct (as in the case of Storm and Sunfire). By Berlant's "franchising" (Queen of America 13) of difference throughout the discourse about the American Dream, the omnipresence of "inevitable America" (Queen of America 16) conserves the ideology of the core white American group, white and mostly male, who tolerate and accept Others in their space, while not allowing them to get too close. This distance is visually perpetuated by various visual codes, their costumes, ways of thinking, and the maintenance of their different identities.

By adapting to the X-Men team, these strangers, non-Americans, can adapt by working and living as well as any American citizen/mutant. In that way, the comic maintains the imaginary of the American Dream, the yearning of non-Americans to come, stay, and succeed in this country, even though they are portrayed as different. Their belonging cannot be fulfilled in entire- 
ty, as the hegemonic tendencies within the discourse, as shown in these examples, maintain the white male Americans in the position of power. These Americans hold the most coveted attributes and values reaffirmed in these comic books, manifested by white people who are the classic and more experienced members (as noted in the analysis of the first X-Men issues), by the image of their leader, professor $\mathrm{X}$, and by his reassuring voice and image, which recruits differently the visually depicted and presented foreign members and reassures them that America will take care of them if they take care of America.

\section{Concluding remarks}

We can interpret this kind of (re)presention of national American qualities as a critique of the exclusion of non-white characters in American popular culture, but this analyzed comic book did not make such an interpretation so plausible and concrete. The reason for this is the stereotyping or "overdetermined narration" (Scott 299) perpetuated by a portrait of an African woman as one with nature, East Europeans as simple-minded folk with simple lives, and Europe in general as a medieval terrain where they burn people who are different from the majority. This kind of strategy is still evident today, with more diverse characters based on nationality, race, sexuality, and gender grounded in a different aspect and cultural citizenship than is most wanted by citizens of America, reminding them, in the most hegemonic way, where they still belong. There has been a gay wedding, Storm is now one of the most famous leaders of the X-men, and parallel to that, we still have various narrative devices that frame them within specific discourses and representations. This paper has noted the beginning of a kind of narrative framing of the American Dream and cultural citizenship that should, and hopefully will, be researched in more detail in the future.

As Berlant notes, the role of one particular medium in constructing the hegemony of the normative nation must be understood as partial and not an absolute moment in the genealogy of national identity crises and the production of national subjects (Queen of America 35). Comic books and graphic 
novels, as seen in the case of THE Giant Size X-Men, have the potential to be a part of a bigger role and bigger picture in which, while providing different and important stories about racism and difference, they still perpetuate and create ways to maintain hegemonic relations between different national subjects. In the case of superhero comic book popular culture, different people could and can be incorporated in American society and yearn for the fulfillment that white, mostly male, American citizens have. But the inability to fully become an American is something that is constantly addressed in many popular culture manifestations through these kinds of representation(s) of difference that the X-Men issues are just one small part.

\section{Works Cited}

Anderson, Benedict. 1991. Imagined communities: reflections on the origin and spread of nationalism. London: Verso, 2006. Print.

Berlant, Lauren. Queen of America goes to Washington City: Essays on Sex and Citizenship. Durham and London: Duke UP, 1997. Print.

---. "Citizenship". Keywords for American Cultural Studies. Ed. Burgett, Bruce and Glenn Hendler. New York: NYU Press, 2007. 37-42. Print.

Cantor, Paul A. "The Apocalyptic Strain in Popular Culture: The American Nightmare Becomes the American Dream." The Hedgehog Review 15.2 (2013).

Foucault, Michael. "Truth and Power." The Essential Foucault. Selections from Essential Works of Foucault, 1954-1984. Ed. Rabinow, Paul and Nikolas Rose. New York: The New P, 2003. Print.

Hall, Stuart. “The Work of Representation." Representation: Cultural Representations and Signifying Practices, edited by Stuart Hall, Thousand Oaks: Sage Publications, 1997. 13-75. Print.

Hassler-Forest, Dan. Capitalist Superheroes: Caped Crusaders in the Neoliberal Age.

Winchester, UK: Zero Books, 2011. Print.

Laclau, Ernesto and Chantal Mouffe. 1985. Hegemony and Socialist Strategy: Towards a

Radical Democratic Politics. London: Verso, 2001. Print.

Marvel Comics. Giant-Size X-Men 40th Anniversary. New York: Marvel, 2015. Print. 
Mills, Sara. Discourse. London: Routledge, 2009. Print.

Neuhaus, Jessamyn. "How Wonder Woman Helped My Students join the Conversation." Pustz, Matthew. Comic Books and American Cultural History: An Anthology. New York: Continuum Int., 2012. 11-26. Print.

Regalado, Aldo J. "Modernity, Race and the American Superhero." Comics as Philosophy Ed. Jeff McLaughlin. Jackson: UP of Mississippi, 2005: 84-99. Print.

Rose, Gillian. Visual Methodologies: An Introduction to the Interpretation of Visual Materials. London: Sage Publication, 2001. Print.

Scott, Anna Beatrice. "Superpower vs Supernatural: Black Superheroes and the Quest for a Mutant Reality." Journal of Visual Culture 5.3 (2006.): 295-314. Web. 10 Nov. 2015. Smith, Philip and Alexander Riley. Cultural Theory: An Introduction, 2nd Edition. Hoboken, New Jersey: Wiley-Blackwell, 2008. Print.

Stavrakakis, Yannis, Aletta Norval and David R. Howarth. Discourse Theory and Political Analysis: Identities, Hegemonies and Social Change. Manchester: Manchester UP, 2000. Print. 